\title{
FAKTOR-FAKTOR YANG MEMPENGARUHI KINERJA SISTEM INFORMASI AKUNTANSI: STUDI KASUS PADA KOPERASI SIMPAN PINJAM DI KABUPATEN GIANYAR
}

\author{
aPutu Agus Satria, ${ }^{\text {bPutu Purnama Dewi }}$ \\ a,b Fakultas Ekonomi dan Bisnis, Universitas Pendidikan Nasional (Undiknas) Denpasar \\ purnamadewi@undiknas.ac.id
}

\begin{abstract}
ABSTRAK
Faktor-Faktor Yang Mempengaruhi Kinerja Sistem Informasi Akuntansi: Studi Kasus pada Koperasi Simpan Pinjam di Kabupaten Gianyar. Tujuan dari penelitian ini adalah untuk menganalisis pengaruh variabel pendidikan dan pelatihan, keterlibatanpengguna dalam pengembangan sistem, serta dukungan manajemen puncak terhadap kinerja sistem informasi akuntansi baik itu secara parsial maupun secara simultan. Populasi penelitian ini ditunjukan kepada karyawan bagian tabungan dan deposito, bagian kredit, serta bagian kasir yang telah memakai sistem IT pada Koperasi Simpan Pinjam di Kabupaten Gianyar sebanyak 78 responden. Metode pengumpulan data menggunakan metode kuesioner. Teknik analisis data yang digunakan dalam penelitian ini adalah analisis regresi linier berganda. Dengan program SPSS 24.0. Hasil penelitian ini menunjukkan bahwa secara parsial pendidikan dan pelatihan, keterlibatan pengguna dalam pengembangan sistem, serta dukungan manajemen puncak berpengaruh positif terhadap kinerja SIA. Sedangkan secara simultan variabel independen berpengaruh terhadap variabel dependen.
\end{abstract}

Kata kunci: Pendidikan dan pelatihan, keterlibatan pengguna dalam pengembangan sistem, dukungan manajemen puncak, kinerja sistem informasi akuntansi

\section{PENDAHULUAN}

Dalam era globalisasi ini, sistem informasi dan teknologi telah berkembang dengan pesat, misalnya dalam bidang informasi dan komunikasi. Perkembangan pengolahan data merupakan salah satu pengaruh dari teknologi komunikasi tersebut. Informasi sangat penting di dalam suatu badan organisasi atau sebuah perusahaan karena merupakan sumber daya bisnisnya. Informasi-informasi tersebut digunakan oleh pihak manajemen atau pihak ekstern yang memiliki kepentingan terhadap perusahaan agar dapat mengambil keputusan yang baik dan dapat mendukung langkah organisasi atau perusahaan tersebut guna memenangkan persaingan.

Perusahaan dan bisnis dapat meningkatkan kinerja melalui penggunaan sarana teknologi informasi (Baig \& Gururajan, 2011). Peningkatan kinerja perusahaan dan bisnis melalui penggunaan teknologi dibutuhkan suatu sistem yang mampu menangkap, menciptakan, dan mengelola informasi dari dalam maupun dari luar. Kemampuan bersaing perusahaan memerlukan strategi yang dapat memanfaatkan semua kekuatan dan peluang yang ada, serta menutup kelemahan dan menetralisasi hambatan strategis dalam dinamika bisnis yang dihadapi. Semua itu dapat dilakukan apabila manajemen mampu melakukan pengambilan keputusan yang didasarkan pada masukan-masukan yang objektif.

Sistem Informasi akuntansi (SIA) merupakan sekumpulan sumber daya, seperti contoh manusia dan peralatan, yang telah dirancang untuk mengubah data keuangan dan data lainnya menjadi sebuah bentuk informasi, informasi tersebut di komunikasikan kepada 
berbagai pihak pengambil sebuah keputusan (Bodnar \& William S Hopwood, 2006). SIA sangat penting bagi sebuah organisasi ataupun sebuah perusahaan agar dapat meningkatkan efisiensi sebuah organisasi dan dapat mendukung daya saing sebuah perusahaan melalui penyediaan informasi keuangan dan akuntansi bagi manajemen (Fahmiswari \& Dharmadiaksa, 2013).

Keberhasilan sistem informasi bagi suatu perusahaan tergantung bagaimana sebuah sistem tersebut dijalankan, kemudahan sebuah sistem bagi para pemakainya, dan pemanfaatan teknologi yang digunakan oleh pemakainya (Goodhue \& Thompson, 1995). Kepuasan dari pemakai SIA dapat menunjukkan bahwa seberapa jauh pemakai akan merasa senang dan percaya terhadap sistem informasi yang digunakan untuk menghasilkan suatu informasi yang sesuai dengan kebutuhannya, mengandung sedikit kesalahan serta mampu menghasilkan informasi yang tepat waktu. Sedangkan pemakaian dari SIA menunjukkan keberhasilan sebuah sistem informasi, apabila frekuensi penggunaannya sering, maka sistem itu dikatakan baik. Agar SIA dapat memberikan sebuah manfaat yang maksimal bagi perusahaan atau sebuah organisasi, maka perlu dilakukan penilaian terhadap kinerja SIA di perusahaan atau organisasi tersebut. Tujuan diadakannya penilaian terhadap kinerja SIA adalah untuk dapat memotivasi karyawan dalam mencapai suatu informasi atau mencapai suatu sasaran organisasi dan dalam mematuhi standar perilaku yang telah ditetapkan agar membuahkan tindakan dan hasil yang diinginkan, (Mulyadi, 2001).

Koperasi adalah sebuah badan usaha atau badan organisasi yang beranggotakan orang seorang atau badan hukum koperasi dengan melandaskan kegiatannya berdasarkan prinsip-prinsip koperasi sekaligus sebagai gerakan suatu ekonomi rakyat yang berdasarkan atas asas kekeluargaan (Pasal 1 UU RI No. 25 Tahun 1992). Koperasi selain untuk mempersatukan kaum ekonomi lemah dan berusaha meningkatkan taraf hidup anggotanya, Koperasi juga merupakan alat perjuangan dalam menyukseskan suatu pembangunan Indonesia kearah yang lebih baik untuk kedepannya. Sehingga koperasi lebih mampu berperan sebagai wadah kegiatan ekonomi rakyat (Wulandari, 2010). Tujuan koperasi agar dapat memajukan kesejahteraan para anggota koperasi dan masyarakat, turut serta dalam membangun suatu tatanan perekonomian nasional dalam rangka agar dapat mewujudkan masyarakat yang adil, makmur dengan tetap berlandaskan pancasila dan UUD 1945 (Pasal 3 UU No. 25 Tahun 1992). Salah satu koperasi yang berkembang pesat di masyarakat adalah 'Koperasi Simpan Pinjam (KSP) dimana program simpan pinjam masih menjadi yang paling diminati oleh masyarakat.

Penelitian sebelumnya tentang SIA antara lain dilakukan oleh Komara (2005) menyatakan bahwa keterlibatan pengguna dan dukungan manajemen puncak berpengaruh terhadap kinerja SIA, sedangkan program pelatihan dan pendidikan tidak berpengaruh terhadap kinerja SIA. Penelitian lain dilakukan oleh Almilia (2007) menyatakan bahwa dukungan manajemen puncak berpengaruh terhadap kinerja SIA dan keterlibatan pengguna dalam proses pengembangan tidak berpengaruh terhadap kinerja SIA. Penelitian yang dilakukan Hari (2014) menyatakan bahwa keterlibatan pengguna serta program pelatihan dan pendidikan berpengaruh terhadap kinerja SIA, sedangkan dukungan manajemen puncak tidak berpengaruh terhadap kinerja SIA. Ketiga variabel ini dinilai sangat mempengaruhi kinerja SIA dari pada faktor-faktor lainnya. Hal ini menyebabkan ketiga variabel tersebut sering di angkat serta layak diteliti. Karena ketidak konsistenan hasil penelitan sebelumnya maka penulis tertarik untuk melalukan penelitian kembali dengan variabel yang sama. Penelitian yang akan dilakukan memiliki perbedaan dengan peneliti sebelumnya, yaitu lokasi penelitian yang dalam penelitian ini dilakukan pada Koperasi Simpan Pinjam di Kabupaten Gianyar. Pemilihan koperasi simpan pinjam sebagai lokasi penelitian karena koperasi simpan pinjam di Kabupaten Gianyar memiliki perkembangan yang sangat baik dari segi penyerapan tenaga kerja, aset yang dimiliki, dan juga berhubungan erat dengan penggunaan sistem informasi akuntansi dan teknologi informasi dalam membantu pekerjaannya. Disamping itu juga masyarakat sekitar khususnya nasabah koperasi sangat mengharapkan informasi yang cepat, sehingga kinerja dari sistem informasi perlu ditingkatkan. Terdapat 121 koperasi simpan pinjam yang beroperasi di Kabupaten Gianyar sampai saat ini dan hampir semuanya sudah 
menggunakan sistem informasi akuntansi untuk menunjang kinerjanya. Berdasarkan uraian yang telah dipaparkan diatas, penelitian ini menguji pengaruh program pendidikan dan pelatihan, keterlibatan pengguna, dukungan manajemen puncak terhadap kinerja sistem informasi akuntansi pada koperasi simpan pinjam di Kabupaten Gianyar. Adapun pemilihan Kabupaten Gianyar karena merupakan salah satu kabupaten di Provinsi Bali yang memiliki perkembangan yang pesat dalam pembangunan di bidang perekonomian serta di bidang lainnya sehingga mendorong lahirnya banyak lembaga penunjang pembangunan tersebut salah satunya koperasi.

\section{KAJIAN LITERATUR}

\section{Technology Acceptance Model (TAM)}

Technology Acceptance Model (TAM) merupakan teori sistem informasi yang memuat model mengenai sikap individu untuk menerima dan menggunakan teknologi ini. Davis 1989. TAM merupakan teori yang paling dapat berpengaruh untuk melihat penerimaan penggunaan sistem informasi. Teori TAM menjelaskan perilaku pengguna teknologi informasi dengan melihat dari persepektif kepercayaan (belief), sikap (attitude), minat (intention) dan hubungan perilaku pengguna (user behavior relationship).

Teori TAM menjelaskan bahwa ada dua faktor yang dapat memengaruhi perilaku personal untuk menerima dan menggunakan teknologi. Dua faktor yang dinyatakan tersebut adalah kemanfaatan (usefulness) dan kemudahan (ease of use (Suhendran, 2012). Kemanfaatan (usefulness) didefinisikan sebagai tingkat sebuah keyakinan individu atau seseorang bahwa pengguna sistem informasi tertentu dapat meningkatkan kinerjanya. Konsep ini dapat menggambarkan manfaat sistem bagi penggunanya yang berkaitan langsung dengan produktifitas, kinerja tugas, dan efektivitas. Kemudahan penggunaan (ease of use) dapat didefinisikan sebagai tingkat dimana seseorang dapat meyakini bahwa penggunaan sistem informasi merupakan salah satu hal yang mudah dan tidak memerlukan suatu usaha kerja keras dari pemakainya. Konsep ini mencakup kejelasan sebuah tujuan pengguna sistem informasi dan kemudahan pengguna sistem untuk tujuan sesuai dengan keinginan pengguna (Davis, 1989).

Kaitan antara model TAM dengan penelitian ini adalah kebermanfaatan dan kemudahan dalam TAM akan mengarah pada penggunaan teknologi secara nyata, sehingga secara tidak langsung pengguna akan terlibat dalam implementasi sebuah teknologi. Kemudahan penggunaan berhubungan dengan pendidikan dan pelatihan yang perlu diikuti atau ditiru oleh pengguna SIA karena dengan pendidikan dan pelatihan dapat meningkatkan pengetahuan secara individu mengenai sebuah manfaat dan kemudahan penggunaan sistem informasi. Kemampuan individu dalam mengoperasikan sistem juga dapat dilatih terus melalui keterlibatan individu selaku pengguna sistem dalam menerapkan fungsi-fungsi pada sistem tersebut. Jika pengguna memiliki pemahaman yang tinggi maka penggunaan suatu sistem jelas akan lebih mudah, selain itu dengan meningkatnya pemahaman pengguna dapat meningkatkan keterlibatan pengguna dalam pengembangan sistem terhadap SIA. Dukungan dari pihak-pihak manajemen untuk pengembangan sistem juga memiliki andil dalam mengukur kinerja sistem. Karena selama ini, pihak manajemen pun menggunakan sistem informasi untuk dapat mengambil sebuah keputusan yang pada nantinya akan ditetapkan. Semakin besar manajemen puncak mendukung dan ikut dalam proses perencanaan pengembangan sistem informasi akuntansi, maka akan memperlihatkan keseriusan manajemen dalam membantu dan mendukung bawahannya dalam pengoperasian SIA sehingga akan meningkatkan kepuasan penggunanya. TAM dapat meyakini seseorang bahwa penggunaan sistem informasi akan memberikan manfaat kepada individu atau organisasi dan penggunaan sistem informasi akan mempermudah penggunanya dalam menyelesaikan suatu pekerjaan (Gupta 2007). 


\section{Sistem Informasi}

Menurut Widjajanto (2001) sistem adalah sesuatu yang memiliki bagian-bagian yang saling berinteraksi untuk mencapai tujuan tertentu melalui 3 tahapan, yaitu input, proses dan output. Sedangkan menurut Mulyadi (2001) sistem adalah sekelompok unsur yang erat berhubungan satu dengan yang lainnya, yang berfungsi bersama-sama untuk mencapai tujuan tertentu. Sistem informasi formal adalah cara-cara yang diorganisasi untuk mengumpulkan, memasukkan, mengolah dan menyimpan data, dan cara-cara yang diorganisasi untuk menyimpan, mengelola, mengendalikan, dan melaporkan informasi sedemikian rupa sehingga sebuah organisasi dapat mencapai tujuan yang telah ditetapkan (Krismiaji dalam Edwardo, 2014).

\section{Sistem Informasi Akuntansi}

Bodnar \& William S Hopwood (2006) menyatakan bahwa sistem informasi akuntansi (SIA) adalah kumpulan sumber daya, seperti manusia dan peralatan yang dirancang untuk mengubah data keuangan dan data lainnya menjadi informasi. Informasi ini dikomunikasikan kepada berbagai pihak pengambil keputusan. Sistem informasi akuntansi mewujudkan perubahan ini, baik secara manual ataupun dengan bantuan komputer. sedangkan menurut (Widjajanto, 2001) Sistem Informasi Akuntansi adalah susunan berbagai formulir, dan laporan yang terkoordinasikan secara erat yang didisain untuk mentransformasikan data keuangan menjadi informasi yang dibutuhkan manajemen.

\section{Kinerja Sistem Informasi Akuntansi}

Kinerja merupakan gambaran mengenai tingkat pencapaian pelaksanaan serta kegiatan atau kebijaksanaan dalam mewujudkan sistem, tujuan, misi dan visi organisasi yang tertuang dalam perumusan skema strategis (Sari \& Ratna, 2009). Penilaian kinerja berhubungan dengan penyelesaian tugas-tugas tertentu, apakah berhasil atau gagal dicapai oleh pekerja. Kinerja yang semakin tinggi melibatkan kombinasi dari peningkatan kualitas. Kinerja yang lebih baik akan tercapai jika individu dapat memenuhi kebutuhan individual dalam melaksanakan dan menyelesaikan tugas.

Jen (2002) mengukur efektifitas sistem informasi dengan menggunakan kepuasaan pemakai dan pemakaian sistem. Soegiharto (2001) dan Choe (1996) mengukur kinerja sistem informasi akuntansi ke dalam dua bagian yaitu kepuasan pemakai sistem (user information satisfaction) dan pemakaian sistem informasi (system usage) sebagai pengganti variabel kinerja sistem informasi akuntansi.

\section{Program Pendidikan dan Pelatihan Pengguna}

Kemampuan dan keahlian seseorang ditentukan dan dipengaruhi oleh pendidikan formal yang pernah ditempuh. (Komara, 2005) menyatakan bahwa sebuah organisasi dalam pengembangan sistem informasi akuntansi harus mengusahakan adanya program pendidikan dan pelatihan bagi pemakai sistem informasi akuntansi. Dengan adanya pendidikan dan pelatihan tersebut, pengguna akan mendapatkan kemampuan untuk mengidentifikasi persyaratan informasi mereka dan kebenaran serta keterbatasan sistem informasi. Tujuan diadakannya program pendidikan dan pelatihan pemakai yaitu meningkatkan kemampuan dan pemahaman pemakai terhadap sistem informasi akuntansi yang digunakan. Selain itu program pendidikan dan pelatihan pemakai dapat membuat pemakai merasa lebih puas dan akan menggunakan sistem yang telah dikuasai dengan baik, sehingga dapat membantu dalam menyelesaikan pekerjaan (Soegiharto, 2001).

\section{Keterlibatan Pengguna dalam Pengembangan Sistem}

Setiap sistem informasi yang dibuat, harus memperhatikan faktor pengguna (user). Hal tersebut dilakukan guna meminimalkan hambatan-hambatan yang akan terjadi jika ada ketidaksesuian antara sistem yang dibuat dengan pengoperasian sistem oleh penggunanya. Menurut Rusmiati (2012), keterlibatan pemakai adalah keterlibatan mental dan emosisonal orang-orang dalam situasi kelompok yang mendorong mereka untuk memberikan kontribusi 
kepada tujuan kelompok. (Komara, 2005) dalam penelitiannya menyatakan bahwa keterlibatan pemakai berpengaruh terhadap kinerja sistem informasi akuntansi. Keterlibatan pemakai yang semakin sering akan meningkatkan kinerja sistem informasi akuntansi dikarenakan adanya hubungan yang positif antara keterlibatan pemakai dalam proses pengembangan sistem informasi dan kinerja sistem informasi akuntansi (Jen, 2002). Pengembangan sistem informasi menuntut adanya peranan pemakai dalam setiap tahap. Keterlibatan pemakai dalam pengembangan sistem informasi lebih ditekankan bagaimana peranan pemakai dalam mengembangkan dan langkah-langkah apa yang dilakukan dalam mendukung dan mengarahkan kontribusinya.

\section{Dukungan Manajemen Puncak}

Manajemen puncak merupakan titik sentral dari sebuah sistem informasi, dimana manajer tersebut menggunakan sistem informasi untuk dijadikan pengambilan keputusan untuk mencapai tujuan tertentu. Setiap aktivitas pengembangan sistem, manajemen puncak memiliki andil yang besar mengenai bagaimana sistem informasi tersebut nantinya akan diarahkan. Dukungan manajemen yang diberikan oleh top management kepada sistem informasi organisasi dapat menjadi suatu faktor yang sangat penting dalam menentukan efektivitas penerimaan sistem informasi dalam organisasi, dan keberhasilan semua kegiatan yang berhubungan dengan sistem informasi, (Soegiharto, 2001).

Jen (2002) dalam penelitiannya menyatakan bahwa keberhasilan kinerja SIA tidak akan lepas dari dukungan manajemen puncak, karena semakin besar dukungan manajemen puncak, maka kinerja sistem informasi akuntansi akan semakin meningkat karena adanya hubungan yang positif antara dukungan manajemen puncak dalam proses pengembangan dan pengoperasian sistem informasi akuntansi.

\section{METODE}

Penelitian ini dilakukan agar dapat mengetahui pengaruh dari pendidikan dan pelatihan, keterlibatan pengguna dalam pengembangan sistem serta dukungan manajemen puncak terhadap sistem infomasi akuntansi. Penelitian ini dilakukan di Kabupaten Gianyar. populasi yang digunakan dalam penelitian ini adalah karyawan bagian tabungan dan deposito, bagian kredit, serta bagian kasir yang menggunakan sistem IT pada Koperasi Simpan Pinjam (KSP) di Kabupaten Gianyar. Teknik pengambilan sampel yaitu menggunakan Purposive Sampling dimana menggunakan pertimbangan yaitu jumlah KSP di Kabupaten Gianyar yang telah menerapkan SIA terkomputerisasi, jumlah KSP di Kabupaten Gianyar yang telah menerapkan SIA terkomputerisasi lebih dari 5 tahun, jumlah KSP di Kabupaten Gianyar yang telah menerapkan SIA terkomputerisasi memiliki total aset lebih dari Rp 1.000.000.000,00.

Data primer dan sekunder peneliti peroleh melalui 2 (dua) cara yaitu, pertama diperoleh dari jawaban sebuah penyataan dalam kuisioner oleh responden. Kedua, data diperoleh dari jumlah karyawan pada KSP yang ada di Kabupaten Gianyar. Teknik pengumpulan data yangakan digunakan yaitu, berupa kuisioner. Dalam penelitian ini teknik analisis data yang akan digunakan adalah analisis regresilinear berganda dengan menggunakan program Statistical Package For Social Science (SPSS). Penyebaran kuesioner dilakukan di 26 KSP di Kabupaten Gianyar. Kuesioner yang disebar sebanyak 78 kuesioner. 
Adapun kerangka pemikiran dalam penelitian ini sebagai berikut :

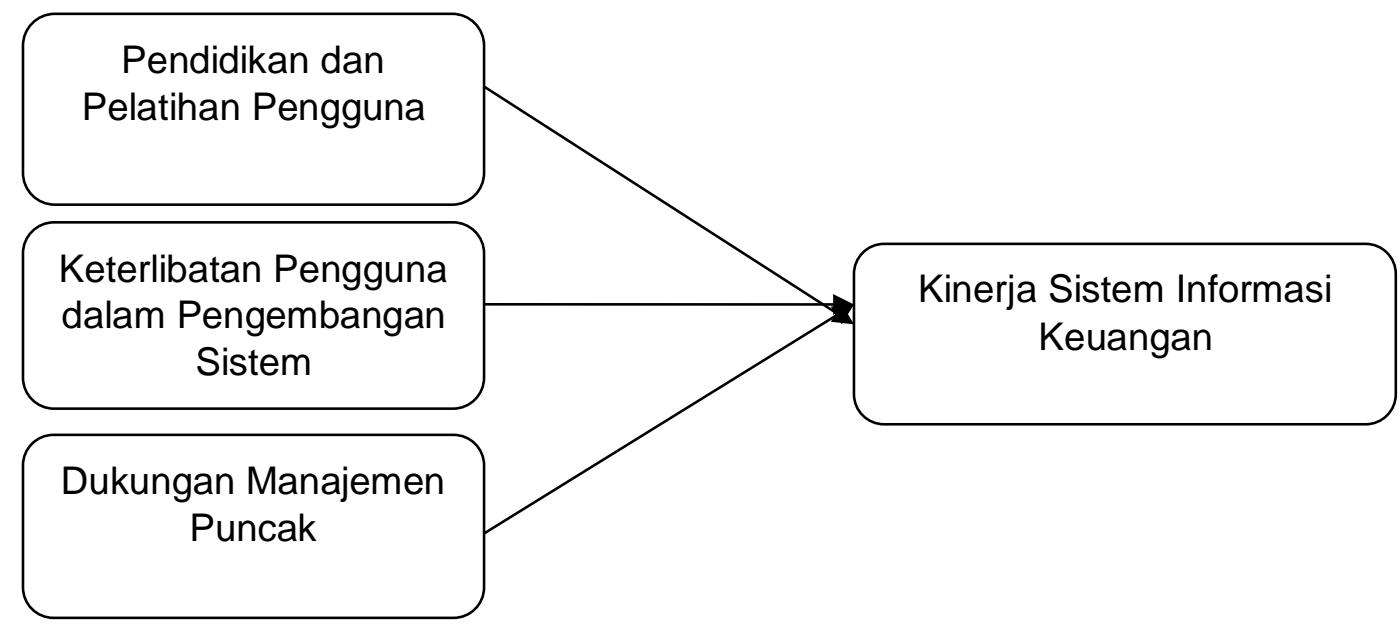

\section{Gambar 1 \\ Kerangka pemikiran}

\section{Pendidikan dan Pelatihan terhadap Kinerja Sistem Informasi Akuntansi}

(Komara, 2005) menyatakan bahwa sebuah organisasi dalam pengembangan sistem informasi akuntansi harus mengusahakan adanya program pendidikan dan pelatihan bagi pemakai sistem informasi akuntansi. Dengan adanya pendidikan dan pelatihan tersebut, pengguna akan mendapatkan kemampuan untuk mengidentifikasi persyaratan informasi mereka dan kebenaran serta keterbatasan sistem informasi. Tujuan diadakannya program pendidikan dan pelatihan pemakai yaitu meningkatkan kemampuan dan pemahaman pemakai terhadap sistem informasi akuntansi yang digunakan, sehingga kinerja SIA akan menjadi lebih baik.

Penelitian yang dilakukan oleh Aryani (2014) menunjukan bahwa program pendidikan dan pelatihan berpengaruh signifikan dan positif terhadap kinerja SIA. Penelitian yang dilakukan oleh (Angelina, 2013) mengungkapkan bahwa pendidikan dan pelatihan berpengaruh positif terhadap kinerja SIA. Penelitian yang dilakukan oleh (S. Hendra, 2013) menunjukan bahwa pendidikan dan pelatihan berpengaruh positif terhadap kinerja SIA. Penelitian yang dilakukan oleh Wicaksosno (2012) menunjukan pendidikan dan pelatihan pengguna berpengaruh positif terhadap kinerja SIA. Penelitian yang dilakukan oleh Ajeng (2015) menunjukan bahwa pendidikan dan pelatihan pengguna berpengaruh positif terhadap kinerja SIA. Hipotesis yang diajukan dalam penelitian ini berdasarkan teori dan penelitian sebelumnya adalah sebagai berikut.

$\mathrm{H} 1$ : Program pendidikan dan pelatihan pengguna berpengaruh positif terhadap kinerja sistem informasi akuntansi.

\section{Keterlibatan Pengguna dalam Pengembangan Sistem terhadap Kinerja Sistem Informasi Akuntansi}

(Komara, 2005) menyatakan bahwa keterlibatan pemakai berpengaruh terhadap kinerja sistem informasi akuntansi. Keterlibatan pemakai yang semakin sering akan meningkatkan kinerja sistem informasi akuntansi dikarenakan adanya hubungan yang positif antara keterlibatan pemakai dalam proses pengembangan sistem informasi dan kinerja sistem informasi akuntansi (Jen, 2002)

Penelitian yang dilakukan oleh (D. Hendra, 2014) menunjukan bahwa keterlibatan pengguna berpengaruh signifikan terhadap kinerja SIA. Penelitian yang dilakukan oleh Ajeng (2015) mengungkapkan bahwa keterlibatan pengguna berpengaruh positif terhadap kinerja SIA. Penelitian yang dilakukan oleh Antari (2015) menunjukan bahwa keterlibatan pengguna 
berpengaruh positif dan signifikan terhadap kinerja SIA. Penelitian yang dilakukan oleh (Hadriansyah, 2015) menunjukan bahwa keterlibatan pengguna berpengaruh positif terhadap kinerja SIA. Penelitian yang dilakukan oleh (Suwira \& Dewi, 2014) menunjukan bahwa keterlibatan pengguna berpengaruh positif terhadap kinerja SIA. Hipotesis yang diajukan dalam penelitian ini berdasarkan teori dan penelitian sebelumnya adalah sebagai berikut.

$\mathrm{H} 2$ : Keterlibatan pengguna dalam pengembangan sistem berpengaruh positif terhadap kinerja sistem informasi akuntansi.

\section{Dukungan Manajemen Puncak terhadap Kinerja Sistem Informasi Akuntansi}

Manajemen puncak memiliki andil yang besar mengenai bagaimana sistem informasi tersebut nantinya akan diarahkan. Dukungan manajemen yang diberikan oleh top management kepada sistem informasi organisasi dapat menjadi suatu faktor yang sangat penting dalam menentukan efektivitas penerimaan sistem informasi dalam organisasi, dan keberhasilan semua kegiatan yang berhubungan dengan sistem informasi, (Soegiharto, 2001). (Jen, 2002) dalam penelitiannya menyatakan bahwa keberhasilan kinerja SIA tidak akan lepas dari dukungan manajemen puncak, karena semakin besar dukungan manajemen puncak, maka kinerja sistem informasi akuntansi akan semakin meningkat karena adanya hubungan yang positif antara dukungan manajemen puncak dalam proses pengembangan dan pengoperasian sistem informasi akuntansi.

Penelitian yang dilakukan oleh (Biwi, 2015) menunjukan bahwa dukungan manajemen puncak berpengaruh terhadap kinerja SIA. Penelitian yang dilakukan oleh (Trisna, 2013) menunjukan bahwa dukungan manajemen puncak berpengaruh positif terhadap kinerja SIA. Penelitian yang dilakukan oleh Kurniatmi (2016) menunjukan bahwa dukungan manajemen puncak berpengaruh signifikan terhadap kinerja SIA. Penelitian yang dilakukan oleh Kasih (2015) menunjukan bahwa program dukungan manajemen puncak berpengaruh positif terhadap kinerja SIA. Penelitian yang dilakukan oleh (Sultan, 2015) menunjukan bahwa dukungan manajemen puncak berpengaruh signifikan terhadap kinerja SIA. Hipotesis yang diajukan dalam penelitian ini berdasarkan teori dan penelitian sebelumnya adalah sebagai berikut.

H3: Dukungan manajemen puncak berpengaruh positif terhadap kinerja sistem informasi akuntansi.

\section{Definisi Operasional Variabel \\ Pendidikan dan Pelatihan Pengguna}

Pendidikan dan pelatihan adalah suatu proses pembelajaran baik secara teoritis maupun secara praktis yang bertujuan untuk peningkatan keterampilan dan pengetahuan individu sehingga terjadinya perubahan sikap dari tidak tahu menjadi tahu. Menurut (Choe, 1996) Pendidikan dan pelatihan pengguna didefinisikan sebagai usaha secara formal untuk tujuan transfer pengetahuan sistem informasi yang diisyaratkan meliputi konsep-konsep sistem informasi, kemampuan teknis, kemampuan organisasi, dan pengetahuan mengenai produk-produk sistem informasi spesifik. Variabel ini diukur dengan menggunakan skala likert 1-4. Menurut Jogiyanto (2009), ada beberapa indikator program pelatihan, diantaranya adalah:
a) Kualitas pendidikan dan pelatihan
b) Prosedur Sistematis
c) Keterampilan teknis
d) Mempelajari pengetahuan
e) Mengutamakaan praktek dari pada teori

\section{Keterlibatan Pengguna dalam Pengembangan Sistem}

Keterlibatan pemakai adalah keikutsertaan individu selaku pemakai SIA dalam mengembangkan SIA yang digunakan. Menurut Aplonia (2014) keterlibatan pemakai digunakan untuk menunjukkan intervensi personal yang nyata pemakai dalam pengembangan sistem informasi, mulai dari tahap perencanaan, pengembangan sampai 
tahap implementasi sistem informasi. Variabel ini diukur dengan menggunakan skala likert 14, dimana poin terendah yaitu 1 dan poin tertinggi yaitu 4. Variabel ini diukur dengan instrumen yang dikembangkan oleh Barki \& Hartwick (Jogiyanto., 2009) menyatakan beberapa indikator yang selanjutnya digunakan juga untuk mengukur keterlibatan pemakai dalam pengembangan sistem dalam penelitian ini. Indikator tersebut adalah sebagai berikut.

a) Keikutsertaan setiap bagian dalam membangun sistem

b) Usulan pengembangan sistem

c) Sumbangan ide atau pikiran pada sistem

d) Rasa memiliki atas sistem

e) Menjaga sistem informasi

\section{Dukungan Manajemen Puncak}

Dukungan manajemen puncak yaitu dukungan yang diberikan oleh pimpinan atas sumber daya yang memiliki kekuatan dan pengaruh untuk mensosialisasikan pengembangan sistem informasi yang memungkinkan pemakai untuk berpartisipasi dalam pengembangan sistem dan ini akan berpengaruh pada kepuasan pemakai. Dukungan manajemen puncak dapat diartikan sebagai pemahaman pimpinan bagian tentang sistem komputer serta tingkat minat, dukungan, dan pengetahuan tentang sistem informasi atau komputerisasi (Rivaningrum, 2015) Variabel ini diukur dengan menggunakan skala likert 1-4, dimana poin terendah yaitu 1, dan poin tertingi yaitu 4. Menurut (Wibowo, 2014), dukungan manajemen puncak dapat diukur dengan indikator sebagai berikut.

a) Kemahiran manajemen puncak dalam pengoperasian komputer

b) Keaktifan manajemen puncak terlibat dalam perencanaan operasi sistem

c) Perhatian manajemen puncak terhadap sistem kinerja sistem

d) Sistem iformasi yang memadai

e) Anggaran penelitian dan ivestasi teknologi informasi

\section{Kinerja Sistem Informasi Akuntansi}

Kinerja SIA adalah gambaran mengenai tingkat pencapaian selama menggunakan SIA dalam periode tertentu. Pengukuran kinerja SIA dapat dilihat dari sisi pemakai (user) dengan membagi kinerja SIA kedalam dua bagian, yaitu kepuasan pemakai dan pemakaian sistem informasi akuntansi. Variabel dependen atau terikat dalam penelitian ini yaitu kinerja sistem informasi akuntansi yang diproksikan menjadi variabel kepuasan pengguna. Kepuasan pengguna menunjukkan seberapa jauh pengguna puas dan percaya pada sistem informasi yang disediakan untuk memenuhi kebutuhan mereka (Ives, 1983). Variabel ini diukur dengan menggunakan skala likert 1-4, dimana poin terendah yaitu 1, dan poin tertinggi yaitu 4. Indikator untuk mengukur kinerja sistem informasi akuntansi menurut (Soegiharto, 2001) diantaranya sebagai berikut.

a) Informasi yang dihasilkan sesuai dengan kebutuhan pengguna

b) Keakuratan informasi

c) Kemudahan akses

d) Kemudahan memahami

e) Kemudahan penggunaan

\section{HASIL DAN PEMBAHASAN}

Penelitian ini menggunakan instrumen berupa kuesioner, dengan obyek penelitian adalah bagian tabungan dan deposito, bagian kredit, serta bagian kasir yang bekerja di Koperasi Simpan Pinjam (KSP) di Kabupaten Gianyar. Penyebaran kuesioner ini dilakukan di 26 KSP di Kabupaten Gianyar. Kuesioner yang disebar sebanyak 78 kuesioner dan 78 kuesioner yang kembali. Jumlah penyebaran dan pengembalian kuesioner disajikan dalam Tabel 1, sebagai berikut. 
Tabel 1

Jumlah Penyebaran dan Pengembalian Kuesioner

\begin{tabular}{|r|l|r|r|}
\hline No & \multicolumn{1}{|c|}{ Nama Koperasi Simpan Pinjam } & $\begin{array}{c}\text { Jumlah } \\
\text { kuesioner } \\
\text { tersebar }\end{array}$ & $\begin{array}{c}\text { Jumlah } \\
\text { kuesioner } \\
\text { kembali }\end{array}$ \\
\hline 1 & Koperasi Simpan Pinjam Puspa Sari & 3 & 3 \\
\hline 2 & Koperasi Simpan Pinjam Mertha Rauh & 3 & 3 \\
\hline 3 & Koperasi Simpan Pinjam Dana Sejahtera Mandiri & 3 & 3 \\
\hline 4 & Koperasi Simpan Pinjam Gianyar II & 3 & 3 \\
\hline 5 & Koperasi Simpan Pinjam Merta Yoga & 3 & 3 \\
\hline 6 & Koperasi Simpan Pinjam Kartika Jaya & 3 & 3 \\
\hline 7 & Koperasi Simpan Pinjam Wira Bhuwana & 3 & 3 \\
\hline 8 & Koperasi Simpan Pinjam Kerta Bhakti Asih & 3 & 3 \\
\hline 9 & Koperasi Simpan Pinjam Tirta Sedana & 3 & 3 \\
\hline 10 & Koperasi Simpan Pinjam Cempaka Danatama Mandiri & 3 & 3 \\
\hline 11 & Koperasi Simpan Pinjam Kharisma Finance & 3 & 3 \\
\hline 12 & Koperasi Simpan Pinjam Jaya Pangus & 3 & 3 \\
\hline 13 & Koperasi Simpan Pinjam Tirta Sedana & 3 & 3 \\
\hline 14 & Koperasi Simpan Pinjam Taman Mandiri & 3 & 3 \\
\hline 15 & Koperasi Simpan Pinjam Artha Winangun & 3 & 3 \\
\hline 16 & Koperasi Simpan Pinjam Binar Dana Rahayu & 3 & 3 \\
\hline 17 & Koperasi Simpan Pinjam Sami Polih & 3 & 3 \\
\hline 18 & Koperasi Simpan Pinjam Lumbung Dewata & 3 & 3 \\
\hline 19 & Koperasi Simpan Pinjam Arta Mulia Jaya & 3 & 3 \\
\hline 20 & Koperasi Simpan Pinjam Karya Sentosa Mandiri & 3 & 3 \\
\hline 21 & Koperasi Simpan Pinjam Merta Sari Bhuana & 3 & 3 \\
\hline 22 & Koperasi Simpan Pinjam. Sedana Mandiri & 3 & 3 \\
\hline 23 & Koperasi Simpan Pinjam Lima Sri Wedana & 3 & 3 \\
\hline 24 & Koperasi Simpan Pinjam Werdhi Laba Sedana & 3 & 3 \\
\hline 25 & Koperasi Simpan Pinjam Dana Prima Abadi & 3 & 3 \\
\hline 26 & Koperasi Simpan Pinjam Anindya Gana Harta & 3 & 3 \\
\hline Total & & 3 & 3 \\
\hline & & 3 & 3 \\
\hline
\end{tabular}

\section{Uji Statistik Deskriptif}

Deskripsi variabel penelitian dapat dijelaskan dengan uji statistik deskriptif. Statistik deskriptif adalah suatu metode dalam mengorganisis dan menganalisis data kuantitatif, sehingga diperoleh gambaran yang teratur mengenai suatu kegiatan. Ukuran yang digunakan dalam deskripsi antara lain: frekuensi, tendensisentral mean, nilai maksimum dan minimum variabel penelitian. Ukuran yang digunakan dalam statistik deskriptif tergantung pada tipe skala pengukuran construct yang digunakan dalam penelitian (Ghozali, 2016:121). Hasil analisis deskriptif pada variabel penelitian ini dapat dilihat pada tabel berikut, 
Tabel 2

Rekapitulasi Uji Statistik Deskriptif Penelitian

\begin{tabular}{|c|c|c|c|c|c|}
\hline & $\begin{array}{c}\text { Pen dan } \\
\text { Pel }\end{array}$ & $\begin{array}{c}\text { Ket } \\
\text { Pengguna }\end{array}$ & $\begin{array}{c}\text { Dunkungan } \\
\text { Man }\end{array}$ & $\begin{array}{l}\text { Kinerja } \\
\text { SIA }\end{array}$ \\
\hline \multirow[t]{2}{*}{$\mathrm{N}$} & Valid & 78 & 78 & 78 & 78 \\
\hline & Missing & 0 & 0 & 0 & 0 \\
\hline \multicolumn{2}{|c|}{ Mean } & 17.63 & 17.82 & 17.71 & 17.35 \\
\hline \multicolumn{2}{|c|}{$\begin{array}{l}\text { Std. Error of } \\
\text { Mean }\end{array}$} & .218 & .225 & .211 & .261 \\
\hline \multicolumn{2}{|c|}{ Median } & 18.00 & 18.00 & 18.00 & 18.00 \\
\hline \multicolumn{2}{|c|}{ Mode } & 17 & 20 & 18 & 17 \\
\hline \multicolumn{2}{|c|}{ Std. Deviation } & 1.921 & 1.985 & 1.866 & 2.307 \\
\hline \multicolumn{2}{|c|}{ Variance } & 3.691 & 3.941 & 3.483 & 5.320 \\
\hline \multicolumn{2}{|c|}{ Range } & 7 & 7 & 7 & 9 \\
\hline \multicolumn{2}{|c|}{ Minimum } & 13 & 13 & 13 & 11 \\
\hline \multicolumn{2}{|c|}{ Maximum } & 20 & 20 & 20 & 20 \\
\hline \multicolumn{2}{|c|}{ Sum } & 1375 & 1390 & 1381 & 1353 \\
\hline
\end{tabular}

\section{Uji Asumsi Klasik}

Syarat suatu data dalam analisis regresi linear berganda adalah terdistribusi secara normal, tidak mengalami multikolinearitas serta terbebas dari masalah heteroskedastisitas. Oleh karena itu, persamaan regresi pada penelitian ini terlebih dahulu dianalisis melalui uji asumsi klasik yang terdiri dari uji normalitas, uji multikolinearitas dan uji heteroskedastisitas.

\section{Uji Normalitas Data}

Uji normalitas bertujuan untuk menguji apakah residual dari model regresi yang dibuat berdistribusi normal atau tidak. Uji yang dapat digunakan adalah uji Kolmogorov-Smirnov (KS). Data dikatakan berdistribusi normal jika taraf signifikansi (Asymp.sig.) diatas 0,05 (Sugiyono, 2017:112).

Tabel 3

Hasil Uji Kolmogorov-Smirnov

One-Sample Kolmogorov-Smirnov Test

\begin{tabular}{|l|l|r|}
\hline \multicolumn{2}{|l|}{} & $\begin{array}{c}\text { Unstandardized } \\
\text { Residual }\end{array}$ \\
\hline N & Mean \\
\hline \multirow{2}{*}{ Normal Parameters } \\
& $\begin{array}{l}\text { Std. } \\
\text { Deviation }\end{array}$ & .0000000 \\
\hline $\begin{array}{l}\text { Most Extreme } \\
\text { Differences }\end{array}$ & Absolute & .29953824 \\
\cline { 2 - 3 } & Positive & .062 \\
\cline { 2 - 3 } & Negative & -.116 \\
\hline \multicolumn{2}{|l|}{ Test Statistic } & .616 \\
\hline \multicolumn{2}{|l|}{ Asymp. Sig. (2-tailed) } & .512 \\
\hline
\end{tabular}
a. Test distribution is Normal.
b. Calculated from data. 
Tabel tersebut menunjukkan nilai Asymp.sig sebesar 0,512 > $\alpha=0,05$ maka dapat disimpulkan bahwa data terdistribusi secara normal.

\section{Hasil Uji Multikolinearitas}

Tabel 4

Uji Multikolinearitas (Tolerance dan Variance Inflation Factor)

\begin{tabular}{|l|c|c|}
\hline \multirow{2}{*}{\multicolumn{1}{|c|}{ Model }} & \multicolumn{2}{c|}{ Collinearity Statistics } \\
\cline { 2 - 3 } & Tolerance & VIF \\
\hline Pendidikan dan Pelatihan & 0,344 & 2.907 \\
\hline Keterlibatan Pengguna & 0,353 & 2.835 \\
\hline Dukungan Manajemen Puncak & 0,678 & 1.474 \\
\hline
\end{tabular}

Hasil uji multikolinearitas pada Tabel di atas menunjukan bahwa nilai tolerance seluruh variabel bebas $>0,1$ dan nilai VIF seluruh variabel bebas $<10$, jadi dapat disimpulkan bahwa data penelitian terbebas dari multikolinearitas.

Hasil Uji Heteroskedastisitas

Tabel 5

Uji Heteroskedastisitas

\begin{tabular}{|l|c|c|}
\hline \multicolumn{1}{|c|}{ Variabel } & Sig. & Keterangan \\
\hline Pendidikan dan Pelatihan & 0,868 & Lolos Uji \\
\hline Keterlibatan Pengguna & 0,356 & Lolos Uji \\
\hline Dukungan Manajemen Puncak & 0,343 & Lolos Uji \\
\hline
\end{tabular}

Tabel di atas menunjukkan seluruh variabel bebas memiliki sig. lebih besar dari 0.05 , maka dapat dinyatakan data penelitian tidak mengalami heterokedastisitas atau terbebas dari masalah heterokedastisitas

\section{Hasil Analisis Regresi Linear Berganda}

Pengaruh pendidikan dan pelatihan, keterlibatan pengguna dalam pengembangan sistem, serta dukungan manajemen puncak dapat diketahui dengan menggunakan analisis statistik regresi linier berganda, $\mathrm{R}^{2}$, F-test dan t-test. Analisis tersebut diolah menggunakan program komputer, yaitu Statistical Package for Social Science 24.0 (SPSS). Hasil analisis regresi linier berganda pada penelitian ini adalah sebagi berikut.

Tabel 6

Hasil Analisis Regresi Linear Berganda

\begin{tabular}{|c|c|c|c|c|c|c|}
\hline \multicolumn{7}{|c|}{ Coefficients $^{a}$} \\
\hline & & \multicolumn{2}{|c|}{$\begin{array}{l}\text { Unstandardized } \\
\text { Coefficients }\end{array}$} & $\begin{array}{l}\text { Standardized } \\
\text { Coefficients }\end{array}$ & & \\
\hline \multicolumn{2}{|c|}{ Model } & B & Std. Error & Beta & $\mathrm{t}$ & Sig. \\
\hline \multirow[t]{4}{*}{1} & (Constant) & 1.204 & 1.667 & & .022 & .009 \\
\hline & PendanPel & .890 & .178 & .560 & 5.013 & .000 \\
\hline & KetPengguna & .136 & .128 & .117 & 3.059 & .003 \\
\hline & $\begin{array}{l}\text { DunkunganM } \\
\text { an }\end{array}$ & .314 & .098 & .254 & 3.198 & .002 \\
\hline
\end{tabular}

a. Dependent Variable: KinerjaSIA 
Tabel di atas menunjukan nilai koefisien regresi dari variabel bebas (pendidikan dan pelatihan, keterlibatan pengguna dalam pengembangan sistem serta dukungan manajemen puncak), nilai konstanta variabel terikat (kualitas audit) serta nilai signifikansi masing-masing variabel bebas, maka diperoleh persamaan regresi linier berganda. Sugiyono (2017:247) menyatakan persamaan tersebut adalah sebagai berikut.

$$
Y=1.204+0.560 X_{1}+0,117 X_{2}+0,254 X_{3}+e
$$

\section{Hasil Uji Koefisien Determinasi $\left(\mathbf{R}^{2}\right)$}

Koefisiendeterminasi $\left(R^{2}\right)$ digunakan untuk mengukur seberapa jauh kemampuan model dalam menerangkan variasi variabel dependen. Hasil dari uji koefisien determinasi dalam penelitian ini ditunjukkan oleh tabel sebagai berikut.

\section{Tabel 7 \\ Hasil Uji Koefisien Determinasi}

\begin{tabular}{|c|c|c|c|c|c|c|c|c|c|}
\hline \multicolumn{10}{|c|}{ Model Summary } \\
\hline \multirow[b]{2}{*}{ Model } & \multirow[b]{2}{*}{$\mathrm{R}$} & \multirow[b]{2}{*}{$\begin{array}{c}\mathrm{R} \\
\text { Squar } \\
\mathrm{e}\end{array}$} & \multirow[b]{2}{*}{$\begin{array}{c}\text { Adjusted } \\
\mathrm{R} \\
\text { Square }\end{array}$} & \multirow{2}{*}{$\begin{array}{c}\text { Std. } \\
\text { Error of } \\
\text { the } \\
\text { Estimate }\end{array}$} & \multicolumn{5}{|c|}{ Change Statistics } \\
\hline & & & & & $\begin{array}{c}\mathrm{R} \\
\text { Square } \\
\text { Change }\end{array}$ & $\begin{array}{c}\mathrm{F} \\
\text { Chang } \\
\mathrm{e}\end{array}$ & df1 & $\mathrm{df2}$ & $\begin{array}{l}\text { Sig. F } \\
\text { Change }\end{array}$ \\
\hline 1 & $\begin{array}{r}.826 \\
a\end{array}$ & .683 & .670 & 1.326 & .683 & 53.040 & 3 & 74 & .000 \\
\hline
\end{tabular}

(Constant), Dunkungan Man, Ket Pengguna, Pen dan Pel

Tabel diatas menunjukkan nilai Adjusted $R$ square adalah sebesar 0, 670 yang berarti variasi variabel bebas dalam model penelitian ini yaitu pendidikan dan pelatihan, keterlibatan pengguna dalam pengembangan sistem serta dukungan manajemen puncak mampu menjelaskan variasi perubahan kinerja SIA sebesar $67 \%$ dan sisanya $33 \%$ dipengaruhi oleh faktor-faktor atau variabel-variabel lain di luar model penelitian.

\section{Hasil Uji-t (Uji Parsial)}

\section{Tabel 8}

\section{Hasil Uji-t}

Coefficients $^{\mathrm{a}}$

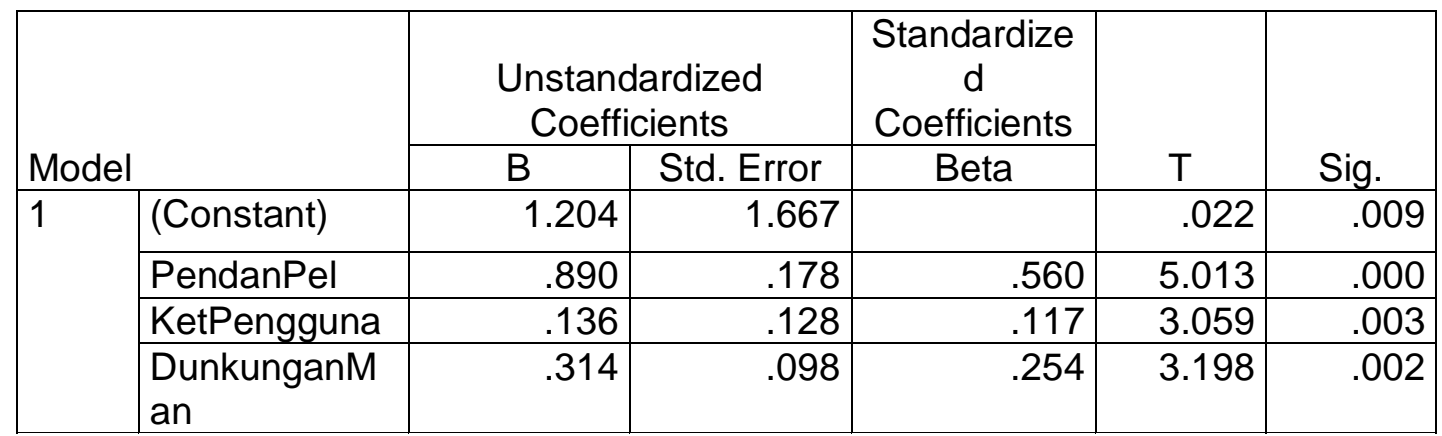

a. Dependent Variable: Kinerja SIA

\section{Pengaruh Pendidikan dan Pelatihan terhadap Kinerja SIA}

Berdasarkan hasil analisis yang telah dilakukan, ditemukan bahwa koefisien regresi pendidikan dan pelatihan adalah sebesar 0,560 , nilai $t_{\text {hitung }}=5,013$ dengan sig.0,000 lebih besar dibandingkan dengan nilai $t_{\text {tabel }}=1,66571$. Oleh karena itu, nilai t-hitung berada pada 
daerah penolakan $\mathrm{H}_{0}$. Hal Ini berarti secara statistik pada $\alpha$ (taraf error) $=0,05$, secara parsial pendidikan dan pelatihan $(\mathrm{X} 1)$ berpengaruh positif dan signifikan terhadap kinerja SIA (Y).

Dengan adanya pendidikan dan pelatihan tersebut, pengguna dapat meningkatkan kemampuan dan pemahaman pemakai terhadap sistem informasi akuntansi yang digunakan. Semakin baik kualitas pendidikan dan pelatihan pada KSP yang berada di Kabupaten Gianyar maka kinerja SIA akan semakin baik. Selain itu program pendidikan dan pelatihan dapat membuat pengguna merasa lebih puas dan akan menggunakan sistem yang telah dikuasai dengan baik, sehingga dapat membantu dalam menyelesaikan pekerjaan pada Koperasi Simpan Pinjam di Kabupaten Gianyar.

Hasil penelitian ini menunjukkan hasil yang sesuai dengan penelitian yang dilakukan oleh Aryani (2014) dan Ajeng (2015) bahwa pendidikan dan pelatihan berpengaruh secara positif terhadap kinerja SIA. Namun Fatmawati (2017) dan Widiantari (2018) dalam penelitian menemukan bahwa pendidikan dan pelatihan tidak berpengaruh terhadap kinerja SIA.

\section{Pengaruh Keterlibatan Pengguna dalam Pengembangan Sistem terhadap Kinerja SIA}

Berdasarkan hasil analisis yang telah dilakukan, ditemukan bahwa koefisien regresi pendidikan dan pelatihan adalah sebesar 0,117 , nilai $t_{\text {hitung }}=3,059$ dengan sig.0,003 lebih besar dibandingkan dengan nilai $t_{\text {tabel }}=1,66571$. Oleh karena itu, nilai t-hitung berada pada daerah penolakan $\mathrm{H}_{0}$. Hal Ini berarti secara statistik pada a (taraf error) $=0,05$, secara parsial keterlibatan pengguna dalam pengembangan sistem (X2) berpengaruh positif dan signifikan (nyata) terhadap kinerja SIA (Y).

Keterlibatan pengguna adalah keterlibatan mental dan emosional orang-orang dalam situasi kelompok yang mendorong mereka untuk memberikan kontribusi kepada tujuan kelompok. Keterlibatan pengguna berpengaruh terhadap kinerja sistem informasi akuntansi, yang semakin sering akan meningkatkan kinerja sistem informasi akuntansi dikarenakan adanya hubungan yang positif antara keterlibatan pengguna dalam proses pengembangan sistem informasi dan kinerja sistem informasi akuntansi yang berarti semakin baik keterlibatan pengguna pada KSP yang berada di Kabupaten Gianyar maka kinerja SIA akan semakin baik.

Hasil penelitian ini menunjukkan hasil yang sesuai dengan penelitian yang dilakukan oleh D. Hendra (2014) dan Hadriansyah (2015) bahwa keterlibatan pengguna dalam pengembangan sistem berpengaruh secara positif terhadap kinerja SIA. Namun Yulianto (2016) dan Rosylowati (2017) dalam penelitian menemukan bahwa keterlibatan pengguna dalam pengembangan sistem tidak berpengaruh terhadap kinerja SIA.

\section{Pengaruh Dukungan Manajemen Puncak terhadap Kinerja SIA}

Berdasarkan hasil analisis yang telah dilakukan, ditemukan bahwa koefisien regresi pendidikan dan pelatihan adalah sebesar 0,254 , nilai $t_{\text {hitung }}=3,198$ dengan sig.0,002 lebih besar dibandingkan dengan nilai $t_{\text {tabel }}=1,66571$. Oleh karena itu, nilai t-hitung berada pada daerah penolakan $\mathrm{HO}$. Hal Ini berarti secara statistik pada a (taraf error) $=0,05$, secara parsial dukungan manajemen puncak (X3) berpengaruh positif dan signifikan (nyata) terhadap kinerja SIA (Y).

Dukungan manajemen puncak bertugas mengarahkan, membina atau mengatur, menuntun dan juga menunjukkan ataupun mempengaruhi. Pemimpin manajemen puncak mempunyai tanggung jawab baik secara fisik maupun spiritual terhadap keberhasilan aktivitas kerja dari yang dipimpin, sehingga menjadi pemimpin itu tidak mudah dan tidak akan setiap orang mempunyai kesamaan di dalam menjalankan ke-pemimpinannya. Kepemimpinan yang berada di perusahaan perlu ditingkatkan perannya kepada bawahannya. Semakin baik kualitas dukungan manajemen puncak pada KSP yang berada di Kabupaten Gianyar maka kinerja SIA akan semakin baik.

Hasil penelitian ini menunjukkan hasil yang sesuai dengan penelitian yang dilakukan oleh Trisna (2013) dan Sultan (2015) bahwa dukungan manajemen puncak berpengaruh secara positif terhadap kinerja SIA. Namun Suroto (2017) dan Suwira (2014) dalam penelitian menemukan bahwa dukungan manajemen puncak tidak berpengaruh terhadap kinerja SIA 


\section{SIMPULAN}

Berdasarkan pembahasan yang telah diuraikan pada bab sebelumnya maka diperoleh simpulan sebagai berikut:

1. Pendidikan dan Pelatihan memiliki pengaruh yang positif dan signifikan terhadap kinerja SIA. Dimana Pendidikan dan Pelatihan memiliki koefisien t sebesar 5,013 dan signifikansi sebesar 0,000 .

2. Keterlibatan Pengguna dalam pengembangan sistem memiliki pengaruh yang positif dan signifikan terhadap kinerja SIA. Dimana keterlibatan pengguna dalam pengembangan sistem memiliki koefisien t sebesar 3,059 dan signifikansi sebesar 0,003.

3. Dukungan Manajemen Puncak memiliki pengaruh yang positif dan signifikan terhadap kinerja SIA. Dimana dukungan manajemen puncak memiliki koefisien t sebesar 3,198 dan signifikansi sebesar 0,002.

4. Pendidikan dan Pelatihan, Keterlibatan Pengguna dalam Pengembangan Sistem serta Dukungan Manajemen Puncak secara bersama-sama (simultan) berpengaruh positif siginifikan terhadap kinerja SIA. Dimana Pendidikan dan Pelatihan, Keterlibatan Pengguna dalam Pengembangan Sistem serta Dukungan Manajemen Puncak secara bersama-sama (simultan) memiliki nilai koefisien $\mathrm{F}$ sebesar 53.040 dan signifikansi sebesar 0,000 .

\section{REFERENSI}

Almilia, L. 2007. Faktor-faktor yang dapat Mempengaruhi Kinerja Sistem Informasi Akuntansi pada Bank Umum Pemerintah di Wilayah Surabaya dan Siduarjo. Jurnal IImiah. STIEPerbanas. Surabaya.

Angelina, F. V. 2013. Pengaruh PartisipasiPengguna, Dukungan Manajemen Puncak, Dan Program Pelatihan Dan Pendidikan Terhadap Kinerja Sistem Informasi Akuntansi Pada Perusahaan Daerah Air Minum (PDAM) Delta Tirta Sidoarjo.

Baig, A. H., \& Gururajan, R. 2011. Preliminary Study to Investigation the Determinants that Effect IS/IT Outsourcing. Journal of Information and Communication Technology Research, 1 (2), 48-54.

Biwi, A. 2015. Pengaruh Kapabilitas Personal Dan Dukungan ManajemenPuncak Terhadap Kinerja Sistem Informasi Akuntansi PT. Tirta Mumbul Jaya Abadi Singaraja. E-Journal S1 Ak Universitas Pendidikan Ganesha.

Bodnar, G. H., \& William S Hopwood. 2006. Sistem Informasi Akuntansi (Keenam). Jakarta.

Choe, J. 1996. The Relationships Among Performance of Accounting Information System, Influence Factors, and Evolution Level of Information Systems. Journal of Management Information System/Spring., 12(4), 215-239.

Fahmiswari, W., \& Dharmadiaksa, I. B. 2013. Pengaruh Kinerja Individual Karyawan terhadap Efektivitas Penggunaan Sistem Informasi Akuntansi. E-Jurnal Akuntansi Universitas Udayana, 5 (3).

Ghozali, I. 2013. Aplikasi Analisis Multivariate dengan Program IBM SPSS 21 Update PLS Regresi. Semarag: Badan Penerbit Universitas Diponegoro, Semarang.

Goodhue, D., \& Thompson, R. 1995. Task-Technology Fit and Individual Performance (19 (2) ed.).

Hadriansyah, M. A. 2015. Faktor-Faktor Yang Mempengaruhi Kinerja Sistem Informasi Akuntansi. Jurnal Ekonomi Dan Bisnis Universitas Muhammadiyah Surakarta.

Hendra, D. 2014. Analisis PengaruhKeterlibatan Pemakai Dalam Pengembangan Sistem Informasi, Dukungan Manajemen Puncak, Dan Formalisasi Pengembangan Sistem Informasi Terhadap Kinerja Sistem Informasi Akuntansi Pada PT. Bank Jateng Cabang Ungaran. Jurnal Akuntansi Fakultas Ekonomi Universitas Dian Nuswantoro Semarang.

Hendra, S. 2013. Pengaruh Kualitas Informasi, Kemampuan Teknik Personal Sistem Informasi Pelatihan Dan Pendidikan Pemakai Sistem Terhadap Kinerja Sistem Informasi. Jurnal Ekonomi Dan Bisnis Universitas Jember. 
Jen, T. F. 2002. Faktor-Faktor yang Mempengaruhi Kinerja Sistem Informasi Akuntansi. Jurnal Bisnis Dan Akuntasi.

Jogiyanto. 2009. Sistem Teknologi Informasi (Ketiga). Yogyakarta: Universitas Gajah Mada.

Komara, A. 2005. Analisis Faktor-Faktor yang Mempengaruhi Kinerja Sistem Informasi Akuntansi. SNA VIII Solo, 15-16.

Mulyadi. 2001. Sistem Informasi Akuntansi (ketiga). Jakarta.

Purwantini, K. 2015. Dukungan Manajemen Puncak, Partisipasi Pengguna Sistem Dan Program Pelatihan Terhadap Pengembangan SIA Di CV Megah Perkasa Utama Semarang. Seminar Nasional Ilmu Komputer (Snik 2015).

Rivaningrum, A. 2015. Faktor-faktor yang Mempengaruhi Kinerja Sistem Informasi Akuntansi pada Rumah Sakit Saras Husada Purwerejo. Jurnal Ekonomi Universitas Negeri Semarang.

Sari, M., \& Ratna, M. 2009. Pengaruh Efektivitas Penggunaan dan Kepercayaan terhadap Teknologi Sistem Informasi Akuntansi terhadap Kinerja Individual pada Pasar Swalayan di Kota Denpasar. Jurnal Akuntansi Dan Bisnis.

Soegiharto. 2001. Influence Factor Affecting The Performance Of Accounting Information System. Gajah Mada International Journal of Business, III.

Sugiyono. 2017. Metodelogi Penelitian Bisnis. (Ketiga). Bandung: CV Alfabeta.

Sultan, M. A. 2015. Kinerja Sistem Informasi Yang Didukung Oleh Manajemen Puncak. Jurnal Ekonomi Dan Bisnis Universitas Pendidikan Indonesia.

Suwira, F., \& Dewi, A. F. 2014. Analisis Faktor-Faktor Yang Mempengaruhi Kinerja Sistem Informasi Akuntansi Pendanaan Pada Perusahaan Yogyakarta, Di. Jurnal Ekonomi, Universitas Atma Jaya.

Trisna, D. 2013. Pengaruh DukunganManajemen Puncak, Kualitas Sistem, Kualitas Informasi, Pengguna Aktual Dan Kepuasan Pengguna Terhadap Implementasi Sistem Informasi Keuangan Daerah Di Kota Denpasar. E-Jurnal AkuntansiUniversitas Udayana.

Wibowo, A. 2014. Analisis DukunganManajemen Puncak, Partisipasi Pemakai Sistem Informasi, Dan Kinerja Sistem Informasi Akuntansi Studi Kasus Pada PT Berlico Mulia Farma. Jurnal Ekonomi Universitas Atma Jaya Yogyakarta.

Widjajanto, N. 2001. Sistem Informasi Akuntansi. Jakarta: Erlangga. 